УДК $821.161 .1+82.95$ (Адамович-Бунін)

Лі Ялінь, аспірант кафедри світової літератури та російського мовознавства Луганський національний університет імені Тараса Шевченка (м. Старобільськ)

\title{
ОЦІНКА Г. В. АДАМОВИЧЕМ ТВОРЧОСТІ І. О. БУНІНА НА СТОРІНКАХ ПАРИЗЬКОГО «ЗВЕНА» (1924-1926 рр.)
}

У паризькому «Звєні» Адамович видав чотири статті про твори І. Буніна, а також багато разів згадував його творчість у зв'язку з розглядом літературних текстів інших авторів. У статті, говорячи про очінку Г. Адамовичем творчості І. Буніна на сторінках паризького «Звєна», звертається увага передусім на безумовне прийняття критиком творів письменника, на близькість їхніх світоглядів. Адамович, так само, як і І. Бунін, не приймає штучність декадансу, надуманість та фальш почуттів. Адамович передає особисті 
враження від прочитаного, підкреслюючи, щ⿻о йому бракує слів, щэоб повною мірою очінити ту або іншу книгу письменника.

Ключові слова: декаданс, критика, оцінка, рецепція, стаття.

В парижском «Звене» Адамович опубликовал четыре статьи о произведениях Бунина, а также много раз упоминал его творчество в связи с рассмотрением литературных текстов других авторов. В статье, говоря об оценке Адамовичем творчества Бунина на страницах парижского «Звена», обращается внимание прежде всего на безусловное приятие критиком произведений писателя, на близость их мировоззрений. Адамович, так же, как и Бунин, не приемлет искусственность декаданса, надуманность и фальшь переживаний. Зачастую Адамович передает личностные впечатления от прочитанного, подчеркивая, что у него не хватает слов, чтобы в полной мере оценить ту или иную книгу писателя.

Ключевые слова: декаданс, критика, оценка, рецепиия, статья.

In Paris «links» Pluzhnik published four articles about the works of Bunin and many times mentioned his work in connection with the consideration of literary texts by other authors. In the article, referring to the Adamovich's evaluation of Bunin's creativity at the pages of Paris «links», author draws attention to the unconditional critic's acceptance of the writer's work, and to the proximity of their worldviews. Adamovich, as well as Bunin does not accept the artificial decadence, artificiality and falseness experiences. Adamovich transmits personal experience of reading, stressing that he did not have enough words to fully appreciate this or that writer's book.

Keywords: decadence, criticism, evaluation, reception, art.

Литературная критика Адамовича занимает большое место не только в русском, но и в мировом литературоведении, поскольку его статьи, заметки характеризуются объективностью и пользовались заслуженным авторитетом у читателей. Мы полагаем, что сегодня необходимо более пристальное внимание уделить критической деятельности Адамовича еще и потому, что современники заслуженно называли его «первым критиком» русского зарубежья. К сожалению, его литературно-критическая деятельность до сих пор не получила достаточного изучения в современном литературоведении, поскольку единственным значительным исследователем рассматриваемого автора является О. Коростелев [Коростелев 1998:7]. Целью статьи стало изучение рецепции Адамовичем творчества Бунина и определение основных аспектов его оценок.

О том, что творчество Бунина интересовало Адамовича, свидетельствуют не только его многочисленные критические статьи и заметки, но и воспоминания, в которых автор создал многогранную характеристику бунинской личности. В парижском «Звене» критик опубликовал четыре статьи о произведениях писателя, а также много раз упоминал его творчество в связи 
с рассмотрением литературных текстов других авторов. Статья «О Бунине» (1924) носит обзорный характер и посвящена главным особенностям бунинского творчества. Уже в начале статьи критик отмечает «достойное внимания обстоятельство»: писателю чужды какие-либо модернистские течения и школы, потому что «это единственный из настоящих писателей послечеховского поколения, оставшийся вполне чуждым и даже враждебным тому позднеромантическому вихрю, который пронесся в нашей литературе в последнюю четверть века и который был назван декадентством, модернизмом и многими другими, столь же условньми именами» [Адамович 1998:29]. По мнению Адамовича, отсутствие связи с модернисткой литературой начала XX века способствует бунинской «непоколебимости», потому что в творчестве писателя «нечему стареть»: «Его проза, даже среди самых «буйных» годов, ничего не потеряла в своей свежести... Его стихи ... лучше стихов почти всех его сверстников, именно благодаря отсутствию всяких «завоеваний»; они прощуе, суще, точнее, приятнее» [Адамович 1998:30]. Здесь критик обращает внимание на невозможность многих авторов эволюционировать над собственными литературными открытиями, которые в начале столетия воспринимались как достижение большой художественной ценности, но уже в 1920-е годы рассматриваются как анахронизм, ретроградство. Бунину же удалось избежать этого явления во многом благодаря и собственному таланту, и стремлению сохранить традиции русской классической литературы. По мнению Адамовича, тургневеское влияние обнаруживается и в чувстве равновесия, которое присуще всему творчеству Бунина, под которым критик подразумевает равную ценность и значимость языка, композиции и замысла: «О прекрасном языке Бунина много писалось. По этому поводу я позволю себе ещуе раз вспомнить имя Тургенева. Как Тургенев, Бунин чувствует равновесие в прочессе творчества: он знает, что язык, как бы богат он ни был, не должен быть развит в ущзерб композиции и замыслу, не должен затмевать их. Так платье не должно затмевать прелести человека» [Адамович 1998:31]. Это равновесие сил в творчестве Бунина позволяет Адамовичу назвать его прозу 
образцом писательского мастерства, отметить умение всегда в полной мере осуществить авторский замысел, «оставляя недоделанными одни куски, дорисовывая до мельчайиих деталей другие».

В завершении статьи Адамович подчеркивает главные особенности бунинского творчества: это и его знание русской жизни, русской культуры, русского человека («Что найдут в нем иностранџ̧ы, которые стали в последнее время усиленно переводить Бунина? Он их, вероятно, не поразит, как вообще не поражает их все наиболее русское и лучшее из русского», замечает критик в финале, словно бы стремясь показать неспособность иностранных читателей понять бунинское творчество [Адамович 1998:31]. Нобелевская премия, полученная Буниным через девять лет после этой статьи, опровергает такое суждение критика), и побуждение читателя, закрывшего книгу, «задуматься над ней» [Адамович 1998:31].

Творчество Бунина, несомненно, близко Адамовичу, он принимает и разделяет его эстетические и мировоззренческие позиции. Неслучайно он посвятил повести «Митина любовь» две статьи, поскольку пытался понять творческие и эстетические установки Бунина. В первой (1925 года) критик кратко и фрагментарно характеризует произведение, подчеркивая, что «Митина любовь» удивила его и что «это одна из самых «человечных» повестей в новой русской литературе» [Адамович 1998:154]. Автор статьи не видит толстовских традиций в повести, но, рассматривая характер главного героя («Сам Митя ускользает, но это так и должно быть при беспредельности его любви. Недаром ведь все влюбленные говорят: «Я схожу с ума». Они с ума не сходят, но перестают быть людьми в обыкновенном смысле слова. Все освещуено для них другим светом, все соотношения меняются, все, что не относится к их любви, кажется им мелочью. Истинно влюбленный - всегда одержимый и, как характер, как личность, он не существует» [Адамович 1998:155]), все же проводит параллель с Анной Карениной, о которой критики говорили, что «о ней нечего сказать, кроме того, что она влюблена» [Адамович 1998:155]. 
То же самое он говорит и о Мите, так же считает, что для его характеристики достаточно слова «влюбленный».

Интересно, что эта статья вышла в июле 1925 года, а уже через полгода, в январе 1926 года Адамович снова вернулся к рассмотрению повести, причем наметил в ней совершенно иные аспекты, позволяющие по-новому ее прочесть. Критик считает, что это произведение служит ключом ко всему творчеству писателя. Весь тон повести обусловлен творческой задачей, которую ставил перед собой художник, его стремлением показать разрушительную силу искусственно созданных обстоятельств, страстей, опошляющих и усложняющих любовь. Для Бунина «мир делится для него надвое, и только одну половину мира он признает и любит. Деление произведено не по моральным, эстетическим и уж, конечно, не по политическим признакам. Нет, это все признаки ничтожные и пустые, слишком грубые и точные. Мир разделен на светлое, простое, доброе, здоровое, бодрое, громкое, с одной стороны, и темное, молчаливое, сложное, лживое, с другой. Давно кто-то сказал: «Бог задумал мир в простоте, все смущуающее пришло от дьявола». Кажется, Бунин мог бы повторить эти слова. Он любит только Божию - в этом смысле - часть мира, и среди людей только божиих, а не дьяволовых nодданныхх» [Адамович 1998:247]. Таким образом, критик выделяет главную особенность бунинского мировоззрения: приятие естественного, простого, Божьего мира и острое неприятие мира искусственного, темного, наполненного декадентскими страстями и переживаниями, скукой, игрой с моралью. Адамович приводит строки из восьмистишия Бунина «Поэтесса», в котором много «злобы и насмешки в описании «декадентки»[Адамович 1998:248]. По его мнению, этой поэтессой вполне могла быть и Ахматова, и то, что Бунин «никогда, ни на минуту не был декадентом, доказывает его высокую сознательность, его художественную честность» [Адамович 1998:247] Именно с этих позиций следует прочитывать «Митину любовь», именно это позволяет понять самоубийство героя как авторское стремление указать на разрушительную силу декаданса: «Скрытылй смысл повести в том, что Митя 
влюблен не в какую-либо подобную себе девушку, а в Катю, девииу, «безумно любямую искусство», поклоннииу музыки Скрябина. Гибель Мити, как жертва, определена не самой его любовью, а вторжением в его жизнь враждебного и опустошающего начала. Катя - существо ничтожное и взбалмошное» [Адамович 1998:249]. Эта заметка о «Митиной любви», на наш взгляд, не только демонстрирует стремление критика постичь писательское мировоззрение, но и является свидетельством близости взглядов Адамовича и Бунина.

Такую же мировоззренческую общность демонстрирует и статья, посвященная «Солнечному удару». Адамович, стремясь подчеркнуть исключительность творчества Бунина, в начале заметки иронично пишет о своих читательских впечатлениях от прочитанных недавно эмигрантских и советских произведений: «Думаю, что это чувство многим знакомо: «ничего не нравится»... Но вот выходит «настоящая» книга, - и сразу оживает интерес, любовь, читаешь ее не отрываясь, не заглядывая, сколько еще странии осталось до кониа, не думая, что можно было бы об этой книге написать» [Адамович 1999:68]. Как и в предыдущих работах, Адамовичу буквально не хватает слов, чтобы передать свое впечатление от прочитанного. И это удивительно, поскольку в статьях о других авторах он всегда дает объективную оценку, проводит точные параллели, определяет достоинства и недостатки. В случае же с произведениями Бунина, критик находится под огромным воздействием таланта писателя. «Признаюсь сразу: я не нахожу нужных слов, чтобы передать свое впечатление... в последних вещах Бунина что-то неуловимое, что ни в описания природы, ни в «чудесный язык» не укладывается и что дает этим книгам очарование. Но об этом «неуловимом» очень трудно говорить» [Адамович 1999:68-69]. В этой статье есть верное замечание о том, что обычно в раннем творчестве писатель «острее и уже по темам, чем в зрелости... устав, притупив зрение, но, расширив кругозор, становится внимательнее $\kappa$ здешней, повседневной мелкой жизни, превращุается в бытописателя» [Адамович 1999:69]. Бунин - это редкий 
пример другой творческой эволюции, он ушел от бытописательства ранних произведений, посвятив творчество исключительно одной теме - теме любви: «У Бунина осталась сейчас только одна тема - любовь. С такой великой, жадной и в то же время просветленной страстью никто, кажется, в русской литературе о любви и не писал. В книге есть не только мастерство, умение, искусство, вдохновение - в них есть счастье» [Адамович 1999:69]. Это последнее предложение критика о счастье, которое нельзя отнести к литературоведческим категориям, а скорее к его личной рецепции, на наш взгляд, является еще одним примером близости автору статьи творчества писателя, его стремлением выделить Бунина из ряда других художников в русском зарубежье.

Таким образом, говоря об оценке Адамовичем творчества Бунина на страницах парижского «Звена», мы обращаем внимание прежде всего на безусловное приятие критиком произведений писателя, на близость их мировоззрений. Он, так же, как и Бунин, не приемлет искусственность декаданса, надуманность и фальшь переживаний. Зачастую Адамович передает личностные впечатления от прочитанного, подчеркивая, что у него не хватает слов, чтобы в полной мере оценить ту или иную книгу писателя. Перспективы исследования данной темы мы видим в изучении эволюции литературнокритических взглядов Адамовича на творчество Бунина.

\section{БИБЛИОГРАФИЯ}

Адамович 1998 - Адамович Г. В. Литературные беседы. Книга первая («Звено» : (1923-1926) / Георгий Адамович. - СПб. : Алетейя, 1998. - 375 с.

Адамович 1999 - Адамович Г. В. Литературные беседы. Книга вторая («Звено» : (1926-1928) / Георгий Адамович. - СПб. : Алетейя, 1999. - 302 с.

Коростелев 1998 - Коростелев О. А. Подчиняясь не логике, но истине... («Литературные беседы» Георгия Адамовича в «Звене») / Олег Коростелев // Адамович Г. В. Литературные беседы. Книга первая («Звено» : (1923-1926) / Георгий Адамович. - СПб. : Алетейя, 1998. - С. 5-30. 